\title{
The overlap spaces of alternative economy and subaltern businesses: a study of emigrant peddlers
}

\author{
Dev Narayan Sarkar ${ }^{1 *}$ and Kaushik Kundu ${ }^{2}$
}

\author{
*Correspondence: \\ devnarayan.sarkar@pepsico.com \\ ${ }^{1}$ PepsiCo India, 4A, Akash Tower \\ 781 Anandapur, Kolkata, West \\ Bengal 700107, India \\ Full list of author information \\ is available at the end of the \\ article
}

\begin{abstract}
Subalterns constitute the large majority of the members of any social system and are closely associated with the geopolitics of any geographical area. Subalterns have often created alternative economies through their networks of solidarity to rally themselves against the hegemonic scourge of mainstream economies. A subaltern business group is identified in the present study, and the applicability of the characteristics of alternative economies is researched. The objective of the present study is to explore the overlapping space of subaltern business groups and alternative economy. The subaltern has often spoken through qualitative studies in the past. The present study embraces the following steps: (a) tracing the evolution of alternative economy with a view to understanding the characteristics of alternative economy; (b) identifying some distinctive characteristics of alternative economic networks; and (c) utilizing the distinctive characteristics of alternative economic networks, to conduct a qualitative study of an organization of subaltern street peddlers. The narratives collected from the subaltern peddlers are used to present certain inferences about the nature of the overlapping space of alternative economy and subaltern businesses. A conceptual framework is constructed for this overlapping space based upon the present study. Such a conceptual framework of the overlapping space of alternative economy and subalterns may add certain important aspects to the simultaneously burgeoning body of academic works on alternative economy as well as subaltern studies. Scholars and policymakers may be able to understand the alternative economic networks of subalterns better and may establish policies for the sustenance of such networks.
\end{abstract}

Keywords: Alternative economies, Community economy, Geopolitical subalterns, Subaltern solidarity, Poor people, Proletariat

\section{Introduction}

The economic crisis of December 2001 in Argentina, and the subsequent hegemonic behaviour by the industrialists of factories gave birth to a movement by unemployed workers to build an alternative economic network through the creation of "productive projects" like bakeries, brick factories, popular education, and child care (Dinerstein 2003). Daya and Authar (2012) integrated the narratives of 12 women members of the Heiveld, a rooibos (herbal tea) producer cooperative in the Northern Cape Province of South Africa, to discern that human development is central to alternative economies.

(c) The Author(s) 2018. This article is distributed under the terms of the Creative Commons Attribution 4.0 International License (http://creativecommons.org/licenses/by/4.0/), which permits unrestricted use, distribution, and reproduction in any medium, provided you give appropriate credit to the original author(s) and the source, provide a link to the Creative Commons license, and indicate if changes were made. 
Subalterns, who for ages have been exploited by hegemonic forces, often create their own alternative economy (McCormack 1981) by manipulating social networks built out of a bonding named "subaltern solidarity" (Ortner 1995). Activism is often a means to social recognition (Reysen and Hackett 2017). Subalterns constitute the large majority of the members of any social system and are closely associated with the geopolitics of any geographical area (Sharp 2011). Grandia (2009) suggested that subalterns play an important role in catalysing social change through their business endeavours.

The term "subaltern", coined from Antonio Gramsci's (1971) writings, refers to subordination in terms of class, caste, culture, gender, race, and language and was used to signify the importance of dominant/dominated relationships in antiquity. However, subalternity may not be restricted to class relations and rather is comprised of exclusion, domination, and marginality in their numerous forms (Green 2011; Perkins 2011). In a sense, groups and individuals marginalized by social and economic hegemony have been conceived as "subalterns" (Spivak 2000, p. 325). In the context of the present study, "subalterns" have been defined as the people who are uneducated farm labourers in their villages. Subalterns have also been referred to as the "humble classes", meaning peasants, artisans, servants, villagers, and so on (Green 2002). In this context, we may ascribe to the term "hegemony", which implies that a given group becomes more dominant and powerful in terms of social and economic position and try to dictate the conditions for the others. Subalterns often participate in alternative economic arrangement that is known as "alternative economy" (North 2010).

A variety of phenomena have been found to be related to that concept (Bianchi and Birtwistle 2010). A comprehensive definition of alternative economy was provided by Haase et al. (2017, p. 1) as follows: "an economy within which actors (1) strive to avoid the effects of economic value creation that harm society or nature, (2) reject the separation of the social and economic spheres, (3) perceive and accept their responsibility for their social and economic activities and the consequences of these activities in the social and natural realms, and (4) attempt to engage in new or revitalized forms of socioeconomic practice".

An inclusive definition of alternative/community economy was provided by Homer (2017), "A community economy, sometimes also known as an alternative community economy, is a type of diverse economy that prioritizes community and environmental well-being, often attempting to reduce global and national dependencies". Campana et al. (2017) highlighted the potentially transformative role of alternative economies. A territorially self-reliant economy results in less pollution and resource depletion, which increases the benefits of community building, development of local and locally oriented social and human capital, ecosystem restoration, and the consequent improved quality of life (Combes et al. 2018; Curtis 2003).

Consequently, an understanding of the alternative economies is critical to understanding the prospects of the world's poorest (Storr and Butkevich 2007). The character of material/social relations is often entangled with the geographies where subalterns operate (Featherstone 2004). Such a contention indicates the academic need for research in the field of subaltern traders, who are subaltern entrepreneurs, specifically in developing economies. Spivak's (1992, p. 46) appealed to "let the subaltern speak", highlighting the need for further research on subalterns. 
While research on alternative economy and on subalterns has been progressing simultaneously, the overlap of these two concepts has been rare. North and Huber (2004) suggested that the characteristics of subaltern entrepreneurs often overlap with those of businesses operating in alternative economy. The forms of transactions conducted by subalterns often fall in the realm of alternative economy (North 2016). A usually less visible function of social movements, which reach out to subalterns, is to provide alternative spaces where the sense of powerlessness may be counteracted (Cassegård 2012). In developing economies, subalterns comprise of a relatively large portion of the total population, and "subaltern economic networks and social environments (SENSEs)" play a pivotal role in the sustenance of subaltern livelihoods (Varman and Vikas 2007). Thus, policymakers, scholars, and economic entities may need to be cognizant of the importance of these networks and the reasons thereof. Consequently, it seems pertinent to study the characteristics of alternative economies that are applicable to the businesses run by subalterns. A subaltern business group is identified in the present study, and the applicability of the characteristics of alternative economies is researched. The objective of the present study, therefore, is to explore the overlapping space of subaltern business groups and alternative economy.

The present study embraces the following steps: (a) tracing the evolution of alternative economy with a view to understanding the characteristics of alternative economy; (b) identifying some distinctive characteristics of alternative economic networks; and (c) utilizing the distinctive characteristics of alternative economic networks, to conduct a qualitative study of an organization of subaltern street peddlers. The narratives collected from the subaltern peddlers are used to present certain inferences about the nature of the overlapping space of alternative economy and subaltern businesses. A conceptual framework is constructed for this overlapping space based upon the results of the present study.

Such a conceptual framework of the overlapping space of alternative economy and subalterns may add certain important aspects to the simultaneously burgeoning body of academic works on alternative economy as well as subaltern studies. Scholars and policymakers may be able to understand the alternative economic networks of subalterns better and may suggest policies for the sustenance of such networks.

\section{Objective of the study}

The phenomenon termed as "outside" development or "anti-development" started prominently figuring in the development frame under the aegis of "alternative economy" in the first decade of the new millennium (Gibson-Graham 2006). Gibson-Graham (2006, p. 87) presented a tabular representation of the characteristics of alternative economy as compared to mainstream economy. The framework separates the mainstream economy from the alternative community economy according to differing values. The mainstream capitalist tenets include elements such as a spatial/global, large-scale, non-local ownership and export oriented. Whereas community and alternative economies reflect contradictory qualities to the mainstream, including place-attached, small-scale, local ownership and ethical, Gibson-Graham's (2006) research focuses on much of the theory behind "capitalocentrism", and creating a new language and landscape for community and alternative economies. 
Heley et al. (2012) assessed Gibson-Graham's conceptualization of alternative community economy as possibly simplistic and consequently limited the ability to systematically view, research, and understand the range of economic activities. They build on GibsonGraham's (2006) binary framework to suggest a new model they call the "compound economy model". The concept of compound economy is influenced by culture and shows its influence on the ways in which local, regional, and global economies interrelate. This model is relatively more multifaceted and capable of explaining more complex phenomenon than. Heley et al's (2012) model pushed beyond the binary model of either "capitalist" or "non-capitalist" economic occurrences by incorporating the capacity to appreciate the "multiple drivers, relations and logics that combine in complex ways to produce, reproduce and transform local and regional economic space" (Heley et al. 2012, p. 368). Compound economy is a specific case wherein some interaction exists between an alternative economic network and the mainstream economy.

Gollnhofer and Schouten (2017) used the term "alternative market arrangement" to mean an alternative subsystem within a market. A particular supply chain may not constitute a market as such, but it may represent an alternative arrangement operating within a more formal market structure. Alternative economies may exhibit historical continuities with a traditional, and non-market exchange system employed by indigenous communities, or may emerge in response to anti-market or anti-consumption sentiments (Gollnhofer and Schouten 2017). The present study seeks to extend the arguments presented by Gollnhofer and Schouten (2017) through a field study of an "alternative market arrangement" and its attributes. While neoclassical economists argue in favour of free markets without any interventions (e.g. Hazlitt 1979), welfare economics focuses on policy interventions for the benefit of the downtrodden (Arrow 1963). This is not as out of place as free market economists would have one believe, because labour is not as freely transferable from poor countries, like India, to developed countries, as goods are transferable from rich countries to the poorer countries (Sassen 1990). Alternative economic system may combine with the traditional framework by the objectification of four dimensions, namely political dimension, social dimension, welfare dimension, and marketing dimension. Hence, instead of reinforcing the present heterodox theory of economics, it may complement and expand the scope of neoclassical theory of economics.

\section{Attributes of alternative economy in developing economies}

As a central concept, the characteristics of alternative economies provided by Campana et al. (2017), in their editorial in a special issue on alternative economies, have been used in the present discussion. While Campana et al. (2017) provided a listing of the characteristics, they did not provide an elaboration of the same. Campana et al. (2017) seemed to have been inspired by the prior works by Gibson-Graham (2006) (The Community Economies Framework, p. 87), and the present study attempts to elaborate these characteristics with the stated objective of validating each of these characteristics in the context of a particular business run by subalterns. The generic framework is presented first followed by its validation with respect to an organization run by subaltern peddlers in a further section, and the consequent presentation of a framework that may be applicable specifically to alternative economic networks of subalterns. Figure 1 presents a listing, as 


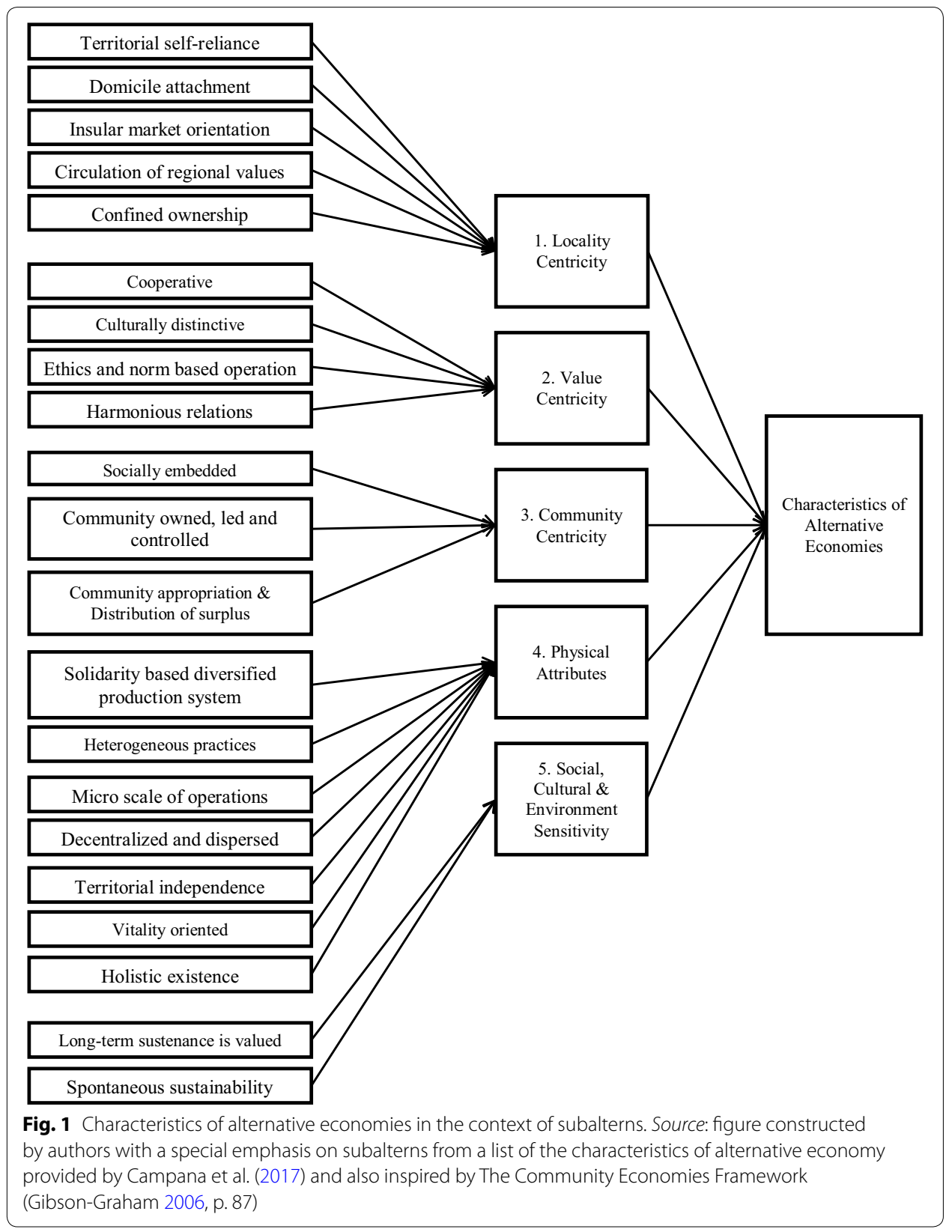

well as a categorization, of the characteristics of alternative economic networks. Each of the elements is explained using extant inferences from the available literature.

\subsection{Territorial self-reliance}

Notions such as "self-reliance" and local equivalents of "Local Economic Development" (LED) appear to be among the alternative economic development options available to the "poorest of the poor", who often get a raw deal from the mainstream economy (Binns and Nel 1999). Shuman (2013) defined self-reliance as the nurturing of locally owned businesses which use local resources sustainably, employ local people, and sell to local people. 


\subsection{Domicile attachment}

Subaltern strategies of localization by communities, place-based strategies that rely on the attachment to territory and culture, encourage the engagement of people from similar subaltern groups in alternative economic communities (Escobar 2001). The alternative economy is often distinguished from the mainstream economy through domicile attachment and small-scale cooperative producers and sellers (Steele 2012). Ballamingie and Walker (2013) studied an alternative economic system named, Just Food, that is, domicile attachment, and rooted in both the Ottawa foodshed and the Greens Creek/Blackburn Hamlet site for procuring and selling local food products.

\subsection{Insular market orientation}

Alternative economic systems strive for the creation of sustainable economies and the establishment of alternative market institutions, such as fair trade and local market systems (DuPuis and Gillon 2009). A small firm with spatially fixed capital and production for the local market has great incentives to build a strong social capital with the local community (Westlund 2003).

\subsection{Circulation of regional values}

Alternative economies should be understood as material circuits of value, the means by which value is consumed, exchanged, and produced (Fickey 2011). Alternative economies and marketplaces are often marked by the prevalence of barter system as Benmecheddal et al. (2017) found developing in Greece after the austerity measures imposed by government stifled the mainstream economy. The role of bartering in ensuring the short-term economic survival of otherwise threatened producers and consumers, the use of alternative currencies as complementary rather than fully antagonistic to conventional currencies, and the underlying agenda of barter economies are some of the bases of alternative economies (Benmecheddal et al. 2017). Collom's (2005) research traced the use of corn to the use of labour time (\$10 equivalent for an hour's labour) as the alternative forms of currency in USA.

The "use of money", which is often taken for granted in formal marketplaces, can lead to many socio-cognitive tensions in other "alternative" contexts (Godinho et al. 2017). The introduction of money into previously non-monetary, alternative economies can lead to many socio-cognitive tensions, if money is perceived as having been imposed from the "outside", and disconnected from traditional ways of life.

\subsection{Confined ownership}

North (2000) suggested that the advocates of alternative economies prefer localized production and consumption since it reduces transport costs, and thus fossil fuel burning, pollution, and the need for roadbuilding. The idea of setting up an alternative economy is based on the opportunity to develop ownership of projects confined to the local people (Dyck 1994). It is hoped that the newly gained institutional skills in 
alternative economies will guarantee the success and confined ownership of the management system over the long term (Galvin and Thorndahl 2005).

\subsection{Tendency to form cooperatives}

Alternative economy is often centred on small-scale cooperative enterprises (Hankiss 1988). Cooperatives in general are not well suited to compete with multinational corporations, given that they are highly specialized at the first handler level (Levi 2001). However, some cooperatives are able to compete like the multinationals, i.e. non-price competition in product differentiation, branding, advertising, research, and capacity expansion (Levi 2001).

\subsection{Culturally distinctive}

Ethnicity is claimed to be the primary basis of perceived distinction between human communities, which can be generally defined as "the existence of culturally distinctive groups within a society, each asserting a unique identity on the basis of a shared tradition" (Xie 2010, p. 2). Such distinctive groups often form alternative economic systems (Homer 2017). Ballamingie and Walker (2013), in their study on an alternative food production community in Ottawa, stated that alternative economies are culturally distinctive and socially embedded (drawing on extensive connections to local producers, restauranteurs, and community supporters).

\subsection{Ethics and norm-based operation}

Baskerville and Dulipovici (2006) found ethics to be a major determinant of the formation and sustenance of alternative economic networks. Parkins and Craig (2009) based their theory of local economic networks on the pivotal role played by ethics in social life. Economic initiatives and enterprises, within alternative economic frameworks, can encourage collective and ethical decision-making rather than individualism, exploitation, and market logics (Shear 2014).

\subsection{Harmonious relations among actors}

Subalterns are suggested to have a collective ethos (James 2015). Diversity, solidarity, and interdependency are the foundations for shared commitments and collective attempts to minimize economic exploitation and to empower local subjects (Campana et al. 2017). "Subaltern peasant revolts" are extreme examples of the strong community solidarity as well as negative opposition to certain perceived exploiters (Chatterjee 2008).

\subsection{Socially embedded}

Analysts and activists alike strive to re-socialize economics so that those whose interests it serves can be recognized and so that innovative, socially embedded forms of exchange can emerge (Maurer 2008). Islamic finance, for example, is a form of alternative economy in certain countries (where it is not the usual form of finance), based upon a socially embedded community (Rethel 2011). Alternative economies focus on acknowledging, recognizing, and even propagating the socially embedded character of economies (Wright 2010). 


\subsection{Community owned, led, and controlled}

"Alternative economies have (re-)emerged in local communities where various groups and social movements are working towards localized development driven by their hope to improve human conditions" (Campana et al. 2017, p. 125). One answer to the issues of citizen participation and local anchoring, transparency for customers, distribution of profits, is when citizens come together to build community-owned businesses pursuing social and environmental aims prior to profit maximization (Huybrechts 2013). Alternative economy projects seek to empower marginalized actors within core community activities such as education systems, labour markets, political institutions, and sociocultural life by emphasizing upon community-controlled businesses (McCauley 2012).

Lauria (1986) asserted that community-controlled implementation organizations are necessary to initiate redevelopment in many areas. Groups based on alternative economic frameworks agree to a common set of principles for community control and democratic governance (Nembhard 2006). Loh and Shear (2015) advocated communitycontrolled financing for the success of alternative economic initiatives. Kröger (2014) studied certain community-controlled tree plantations, whose benefits included distributing benefits equally to the community members.

\subsection{Community appropriation and distribution of surplus}

St. Martin (2007) suggested the presence of an alternative "livelihood" economy where surpluses generated from common resources are "shared" among the members of alternative economy within specific places. Community appropriation and distribution of surpluses are highlighted by Smith (2012) as the building blocks of an alternative economy. Tolley and Hall-Arber (2015) studied the Fish Locally Collaborative (FLC) of New England that promotes diversity with small-scale fisheries as an alternative economy. The "lay system of payment" in which fishermen receive a share of the proceeds from the catch rather than a wage is an indicator of this alternative economy (Tolley and HallArber 2015).

\subsection{Solidarity-based diversified production system}

Diversity, solidarity, and interdependency are the foundations for shared commitments and collective attempts to minimize economic exploitation and to empower local subjects (Campana et al. 2017). The societally defining differences at the symbolic centre of subalterns' identities motivate them to strive for social recognition from the broader society through their alternative economic networks (Thompson 2014). Diversity in production methods is a notable feature of alternative economic systems (Steele 2012).

\subsection{Heterogeneous practices}

Dansero and Puttilli (2014) suggested the existence of multiple territorialities of alternative food networks. Alternative economic networks involve heterogeneous activities (Ofstehage 2012). Alternative economy involves heterogeneous practices, which in turn enables us to see the material, cultural, and subjective impacts of these heterogeneous organizational forms (Bergeron and Healy 2013). Multiple heterogeneous economies coexist in the larger context of the informal economy within a country (Bureau and Fendt 2011). 


\subsection{Microscale of operations}

The microscale of operations in the alternative economy spawns a sense of well-being that is good for labour market participation or for that community (Amin 2005). Many of the more mainstream organic companies, offering produce, grains, and processed goods, started as "small-scale firms" dependent on a politically or nutritionally aware consumer who purchased food in alternative marketing channels such as coops or food clubs (Belasco 2014).

\subsection{Decentralized and dispersed}

The emergence of the idea of a self-conscious, multi-local, alternative economy highlighted the decentred nature of this form of resistance to the mainstream economy (McMurtry 2004). Decentralizing capitalism and entrepreneurship to local communities is a recurring objective in the formation of alternative economies (Smith 2012). Via the experience of Alliance to Develop Power (ADP) and Nuestras Raíces (Our Roots), two long-standing community organizations of the Pioneer Valley of Massachusetts researched by Graham and Cornwell (2009), the domain of economy was shown to be enlarged and radically decentred, becoming an unstructured space of diversity, no longer colonized by the master signifier of capitalism. Tolley and Hall-Arber (2015) studied the long history of alternative economies constituting of successful small-scale, familyowned businesses dispersed in small hamlets. Supporters of alternative economics seek to avoid the negative repercussions of both markets and bureaucratic planning by eliminating the "problem" these allocative mechanisms address-coordinating a division of labour among geographically dispersed groups (Galvin and Thorndahl 2005).

\subsection{Territorial independence}

Daya and Authar (2012) attempted to understand how cooperative members reaped the benefits of participating in an alternative economy by their products being shaped particularly through work which is territorially independent, while connections with others are valued especially for their businesses. The practice of an "alternative" economy produces an assemblage of place-specific practices and institutions that may be described as "relatively autonomous spaces" (Vanolo 2013).

\subsection{Vitality oriented}

If one looks at alternative economies from modes of governance perspective, one can also argue that such economic systems will always include public deliberation and that the vitality and growth of these markets will always depend upon democratic engagement (DuPuis and Gillon 2009).

\subsection{Holistic existence}

Studies in alternative economies concern themselves with the society as a whole and, at the same time, provide the instruments needed to make the social economy work (Moulaert and Ailenei 2005). The ideal of alternative economy is to enable a holistic existence by empowering whole communities through comprehensive management of social and physical conditions (Stoecker 1997). It has to address humanity as a whole and the world society we are making (Hart et al. 2010). 
Long-term sustenance is valued. The concept of sustainable development has met with great success in the fields of ecology and the alternative economy, and where the continuous development of human capabilities is seen as a profitable long-term investment for both individuals and society (Marquié and Duarte 2008). Engendering alternative economic systems often means a long-term investment of time and manpower, which binds people with the places of their economic activities (Jacobi 2016).

\subsection{Spontaneous sustainability}

The alternative economy is distinguished from the mainstream economy through the diversity of processes of production and products, the amount of surplus, and the orientation towards environmental and socially responsible practices (Steele 2012).

From the preceding discussions on the characteristics of alternative economies, it is observed that the underlying theme of the identified elements seems to be a survivalist attitude. Participants form alternative economic networks to survive in the face of larger organizations that operate within the mainstream economy. Alternative economies continuously adjust to the environment for existence. As depicted in Fig. 1, these characteristics of alternative economies may be grouped into the following: (a) locality centricity; (b) value centricity; (c) community centricity; (d) physical attributes; and (e) social, cultural, and environment centricity. Having identified the characteristics of alternative economies from the extant literature, these characteristics may now be studied in the context of subalterns.

\section{Formation of alternative economies by subalterns in India}

\subsection{Subalterns in India}

The global restructuring in the developing economies has been the double process of integration with the global economy, on the one hand, and social exclusion and informalization, on the other (Bayat 2000). These processes have led to the further growth of a marginalized and deinstitutionalized subaltern in developing economies (Bayat 2000).

Gramsci identified slaves, peasants, religious groups, women, different races, and the proletariat as subaltern (Green 2002). Such a contention subsumes the Marxian concept of "proletariat" as one of the groups that Gramsci (1971) classifies as subalterns. Green (2011) confirmed that Gramsci did not use "subaltern" as merely a code word or euphemism for "proletariat". However, for Spivak (1990), the subaltern classes are not just the oppressed; the subaltern groups are those people that are so displaced they lack political organization. It is in this sense that she contends that the proletariat is not a subaltern group because it is organized in most instances (Spivak 1990). Thus, Spivak (1990) precludes "proletariat" from the definition of subaltern classes.

The concept of alternative economies, as succour for subaltern people in India, seems to be as relevant in the present times when governance still follows the logic of dominance above all (Beasley-Murray and Moreiras 2001). A case study from Kerala province in India affirms that alternative economies have the ability to transform the lives of poor people through collective enterprises (Gibson-Graham 2016). Touri (2016) explored alternative economic networks in India through the case study of a community of Fairtrade, organic farmers in South India-the Indian Organic Farmers Producer Company Limited (IOFPCL) - and their foreign buyers, a group of small private enterprises. 
The Warna Bazar cooperative movement, formed by rural inhabitants to enable the marketing of their produce to their fellow members, is an appropriate example of alternative economy (Kumar and Babu 2013). Tribeni Floating Markets, a set of retailing barges operated by a cooperative on the Alapuzho backwaters of Kerala (a state in India) to service the island villages, is another example of alternative economic networks (Sarkar 2013). The concept of "Haat" (periodic markets in rural India) is an age-old phenomenon that has engendered alternative economic networks since villagers sell their produce in these markets and buy or barter the goods which they need (Velayudhan 2014).

\subsection{Alternative economic networks by subalterns in India}

Salvatore (2003) categorized the class of poor peddlers, shopkeepers, and traders operating in rural areas as subaltern in nature. Salvatore (2003) suggested that "wandering peysanos" (street peddlers, p. 394) are a class of subaltern traders. The street peddlers at the centre of Kothari's (2008) account are "artful political subjects" whose everyday cosmopolitan practices shape the political picture of a marketplace and often extend to the community. Abdullah (2016) observed that mobile trading (hawking) is now a full-time occupation for Freetown's (in South Africa) teeming subaltern population.

Marketization itself often creates new groups of subaltern from that part of the population which fails to convert capital from their traditional field to the new economic fields (Vikas et al. 2015). The business of subaltern peddlers has been claimed to be a social activity involving solidarity within subaltern groups (Salvatore 2003). Such entities assume importance as they produce positive socio-economic impact in the form of better livelihoods and reduce social strife, as explained by Tugba Kocabiyik (2017).

In the floods of Uttarakhand, a state in India, in 2013, it was found that the villages in the districts of Uttarkashi, Tehri, and Pauri Garhwal, could subsist better despite all connecting roads being washed away because of their well-built alternative economic networks (Srivastava et al. 2015). The rich diversity of Non-Wood Forest Products in Indian forests generates alternative income opportunities with many local communities using forest produce for livelihood and planting new trees to replace the ones cut down for local use (Painkra et al. 2017). Gandhi, the father of the nation, had wanted everyone to have a breathing space in his alternative economy to find one's own livelihood with dignity and freedom in self-contained villages (Nadkarni 2015). Hazare (1997) created one such alternative economy in a village named Ralegan Siddhi, in the state of Maharashtra, India.

Although enough research exists on subaltern consumers (Varman and Belk 2008), there is a need for further theorization on subaltern entrepreneurs in the context of alternative economies (Tugba Kocabiyik 2017). Peddling by subalterns has been claimed to be a social activity involving solidarity within subaltern groups (Salvatore 2003).

\section{Background}

The subaltern is often so disarmed by attention that the responses are lamentably unreliable (Sharpe and Spivak 2003). It is often suggested that research on subalterns should involve "studying with the subalterns" rather than "studying the subalterns" (Mato 2000). 
Subaltern research should involve the subalterns themselves, drawing on Spivak's call for "learning from below" (Kapoor 2008, p. 56).

The subjects of the present study are illiterate emigrants from Mahnar (see Fig. 2), a village in the Mahnar subdivision of the Vaishali district of Bihar (a state in India). These emigrants come to Kolkata (see Fig. 2), in the state of West Bengal, the largest metropolis in Eastern India. The migration of subalterns to larger cities is often claimed to lead to the emancipation of themselves and their native villages (De Haas 2006). They speak the Bhojpuri language. Bhojpuri is an Indo-Aryan language spoken in some parts of Uttar Pradesh, Bihar, and Jharkhand, which are states in India.

Poverty-stricken rural people in India, whose primary occupation is agriculture, often migrate to cities in search of an alternative livelihood. This happens mainly during the non-agricultural seasons in India. Seasonal migration is always a very interesting phenomenon to observe in India as the bulk supply of the physical labour, even in cities, comes from village areas. All these people may be identified under the category of "migration for livelihood".

However, all these village-based migrant workers may not be called subalterns, as suggested by the definition given earlier (Haase et al. 2017, p. 1). Another interesting point is that emigration presumes the concept of seasonality. However, in the case of migration, often the particular individual or group of people may settle down permanently in city areas and often change their characteristics of subalternity.

The subjects of the present study speak the language known as Bhojpuri, which has some similarities with Hindi, the national language of India. A generation ago, a poor emigrant from that district, Mr. Amarnath Shaw, came to Kolkata to find some work as a labour and hawker in the streets of Kolkata. After working for a score of years and building some capital, Amarnath started calling other illiterate villagers to Kolkata.

Since groups and individuals marginalized by social and economic hegemony have been conceived as "subalterns" (Spivak 2000, p. 325), the subjects of the present study appear to be subalterns. They are the "humble classes", which includes villagers and

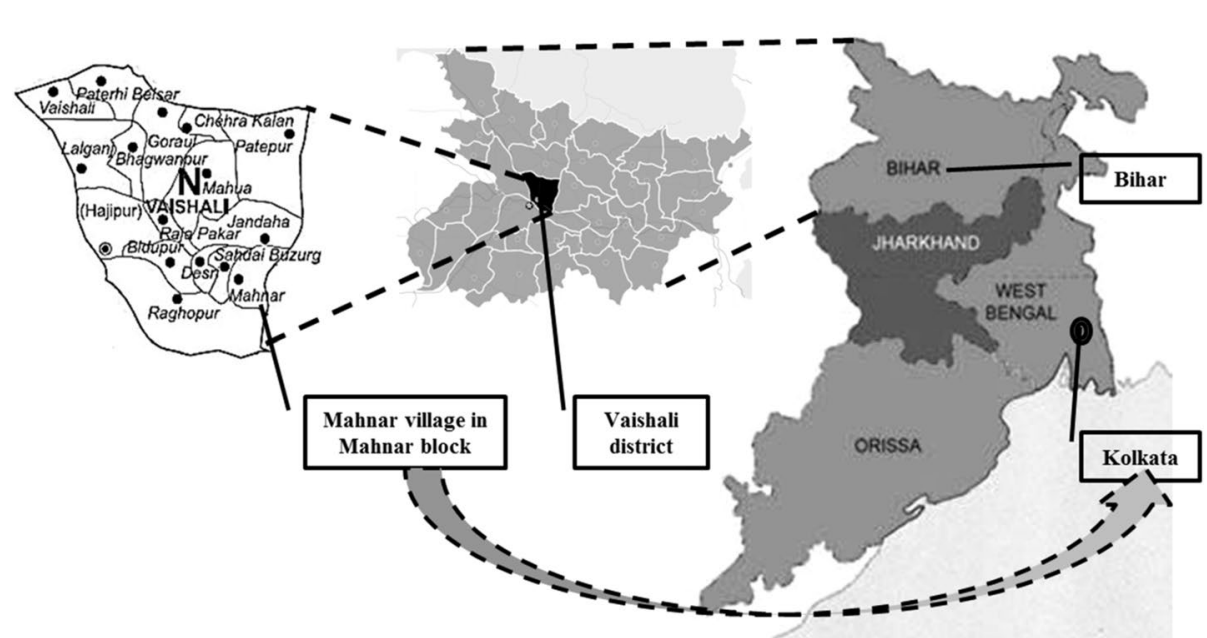

Fig. 2 Geographical locations of the places mentioned in the present study. Source: figure constructed by authors for representation only and is not to scale 
petty tradesmen, as defined by Green 2002. Going by the comprehensive definition of alternative economy that was provided by Haase et al. (2017, p. 1), the chosen subjects may be claimed to be operating within an alternative economic network since they (1) strive to avoid the harmful effects of economic value creation by not using any factory produced goods and by avoiding polluting vehicles, (2) work in groups along with their subaltern brethren, thus merging the social and economic spheres, (3) accept the social and environmental responsibilities of their actions, and (4) attempt to engage in the peddling business on the streets of Kolkata, a revitalized form of socio-economic practice. This may be seen as a case of a "subaltern economy evolving within capitalism" (Fraser and Ettlinger 2008, p. 1648).

These subalterns from his home village of Mahnar, in Vaishali district of Bihar (a state in India), visited Kolkata for a couple of months at a time. The subalterns are supplied daily with some locally made snacking products, in sealed packages, stacked in a three feet by three feet wooden tray to be carried on their heads. The subaltern head-load hawkers sell these products at street crossings at Rs. 5 per packet. In the evening, these street hawkers return to the warehouse of Amarnath, pay back Rs. 3 per packet to Amarnath, and keep Rs. 2 per packet as profits.

They sleep on the warehouse floor on flimsy mattresses. At the end of 2 months, these subalterns return to their villages with Rs. 10,000-20,000 cash. There is no concept of banking among these poor and illiterate villagers, but the cash in hand with them is a veritable fortune for them. Amarnath is their only touchpoint with the formal economy that supplies them with packets of snacking products.

Since the subalterns are more open when discussing things with their own brethren, Amarnath was retained as the interlocutor between the researchers and the subaltern peddlers. A process of long interviews (as suggested by McCracken 1988), often in groups (Frey and Fontana 1991), was chosen for data gathering to allow the subjects to expound upon their beliefs, life situations, and societal norms. Bewley (2002) recognized interviews as an important empirical tool in economic research.

There were two hundred and twelve subalterns operating from the warehouse at the time of the present study. Cochran's (1977) formula for finite population was used to calculate the necessary sample size of 64 , using a confidence level of $86 \%$ (corresponding $Z$-score is 1.48 , and confidence interval is 0.14 ) and a $p$ value of 0.5 .

Sample size for infinite population $=(Z \text {-score })^{2} * p *(1-p) /($ confidence interval $)$

$$
=(1.48)^{2} * 0.5 *(1-0.5) /(0.14)=28=\mathrm{SS}
$$

SS is the sample size calculated using an assumption of infinite population.

Since the population is finite, Cochran's (1977) correction formula is used as follows:

Sample size for finite population $=\mathrm{SS} /(1+((\mathrm{SS}-1) /$ Population $))$

$$
=28 /(1+((28-1) / 212))=25
$$

A random number table was used to select the 25 respondents from the universe of 212 subalterns using a random number table in situ. Interviews of twenty-five subaltern peddlers were conducted by the researchers with the help of the interlocutor. 
All the respondents were made to sit together since subaltern consciousness has been suggested to be an emergent collective consciousness (Spivak 2003). The language used was a mix of Hindi (the national language of India) and Bhojpuri (a language spoken in the state of Bihar).

\section{Data collection and analysis}

Interviews began with ice-breaking inquiries about the history of the operations and the well-being of the respondent (considered as polite, ice-breaking questions). Open-ended questions on the general business situation in the streets were asked. This was followed by open-ended questions on the economic environment of the head-load peddling business. The subaltern interlocutor requested each subject to respond to ten specific openended questions. The broad open-ended questions that were asked are related to the elements presented in Fig. 1. These questions are enumerated in Table 1.

The answers were duly recorded by the researchers who are also experts in the regional vernacular. The narratives were translated from Hindi to English by the authors.

The analysis of the qualitative data was conducted through the use of MAXqda software that helps in the systematic analysis of qualitative data (Godau 2004). Qualitative data analysis (QDA) attempts to develop an understanding of the social reality and to develop relevant conceptualizations about a particular social phenomenon (Denzin and Lincoln 2002). In the present study, data entry and analysis were supported by MAXqda software which facilitates data management, the assignment of labels, codes, and themes to text fragments and the generation of thematic matrices containing these elements (Odusola et al. 2011).

Performing qualitative data analyses with MAXqda enables the construction of empirical types of actions, situations, experiences, or attitudes while conducting a case-based analysis (Godau 2004). The qualitative interview data, after transcription, was analysed by means of content analytical techniques: fragments containing the subaltern peddlers' ideas about major themes, for example regarding the shared nature of decision-making, were identified from each interview and coded. Similar codes were assigned to related statements, causing a "code list" for each interview to be created (as suggested by, Odusola et al. 2011). Code lists were assessed to identify common and unique themes, using MAXqda software, leading to a thematic matrix for the characteristics of the subaltern peddlers (each theme highlighting an antecedent of buying behaviour). Likenesses, differences and patterns between the themes were compared, using these matrices. The common behaviorial themes identified by these resultant matrices are represented in Fig. 3 and are enumerated in Table 1. These narratives collected from the subaltern peddlers were analysed to draw certain inferences about the structure of the alternative economy and the interaction of alternative economy with the mainstream economy.

\section{Findings}

The findings on the overlaps between subaltern business characteristics and alternative economic networks, as inferred from Table 1, are depicted in Fig. 3 and discussed below. The dashed boxes and arrows (in Fig. 3) denote weak characteristics, while the solid boxes and arrows depict strong characteristics of the overlapping space between subalterns and alternative economies. This may be seen as an interdisciplinary study, as 


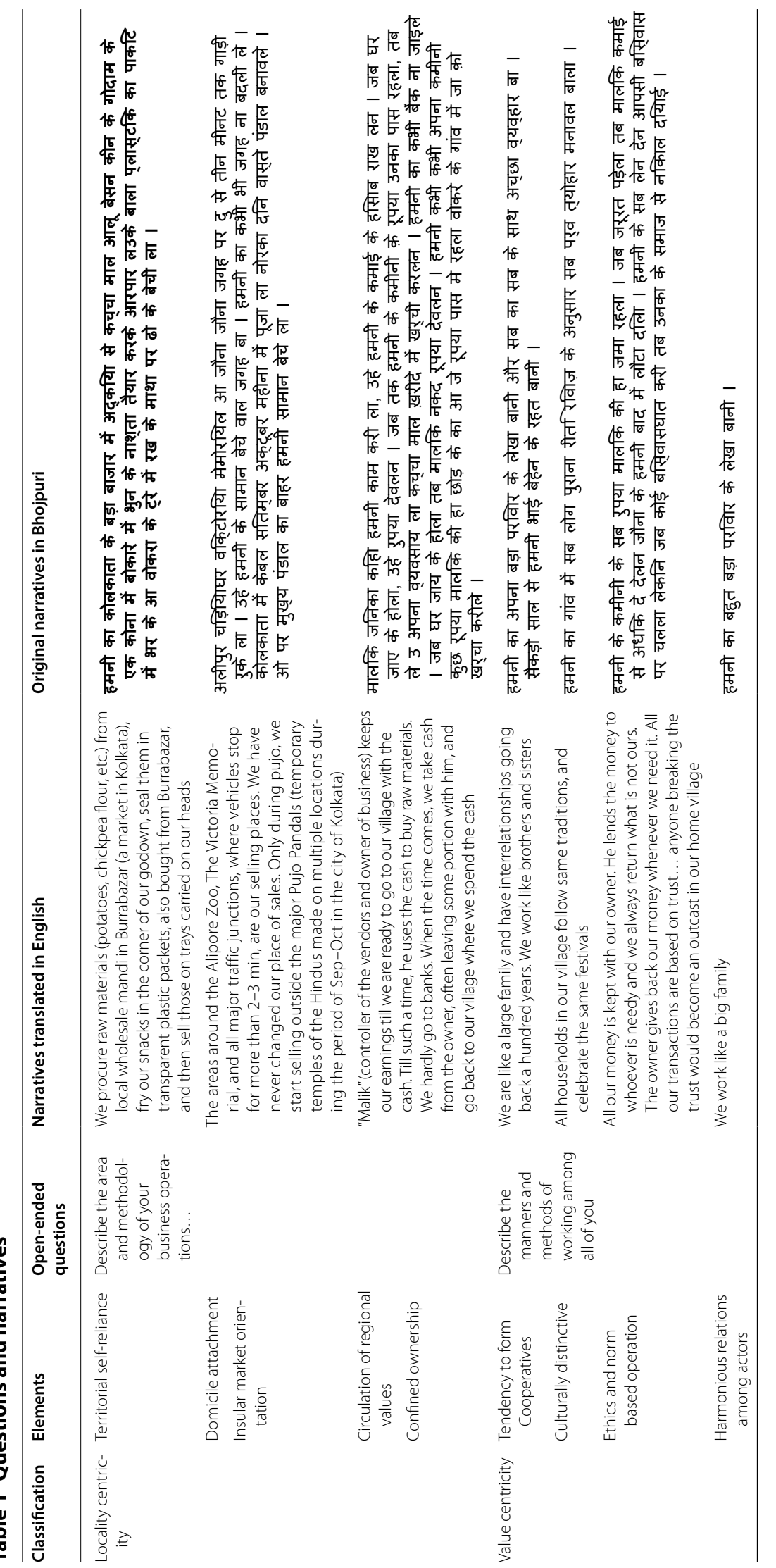




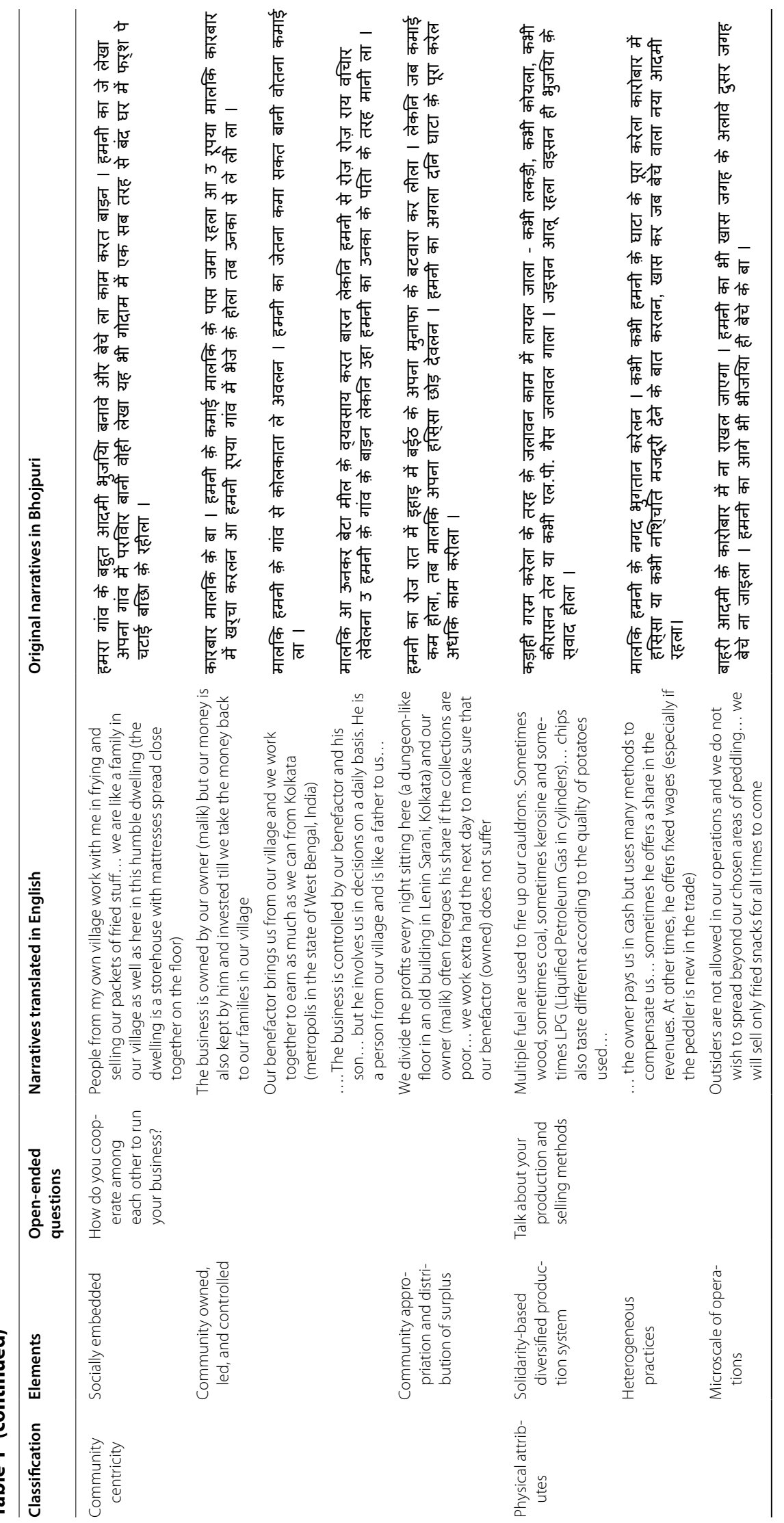




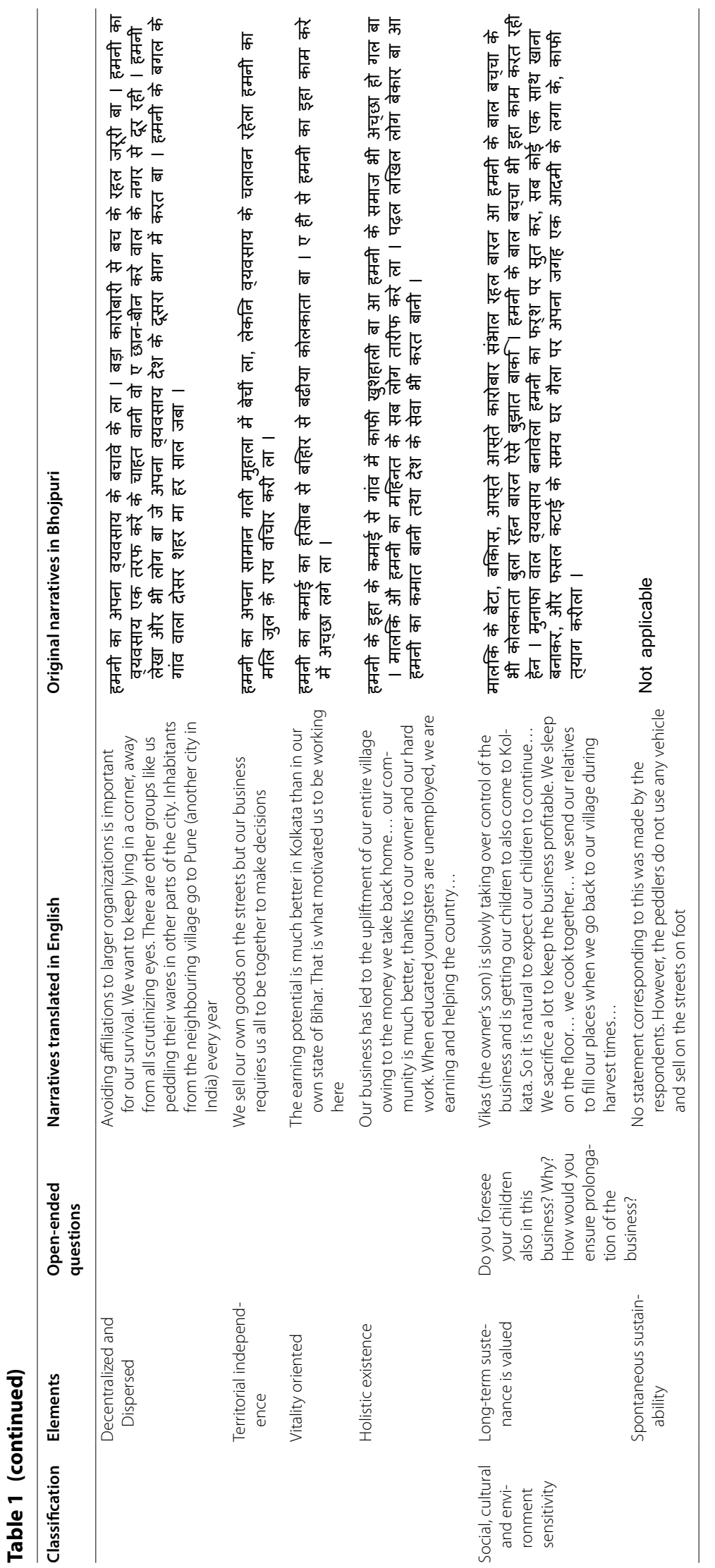




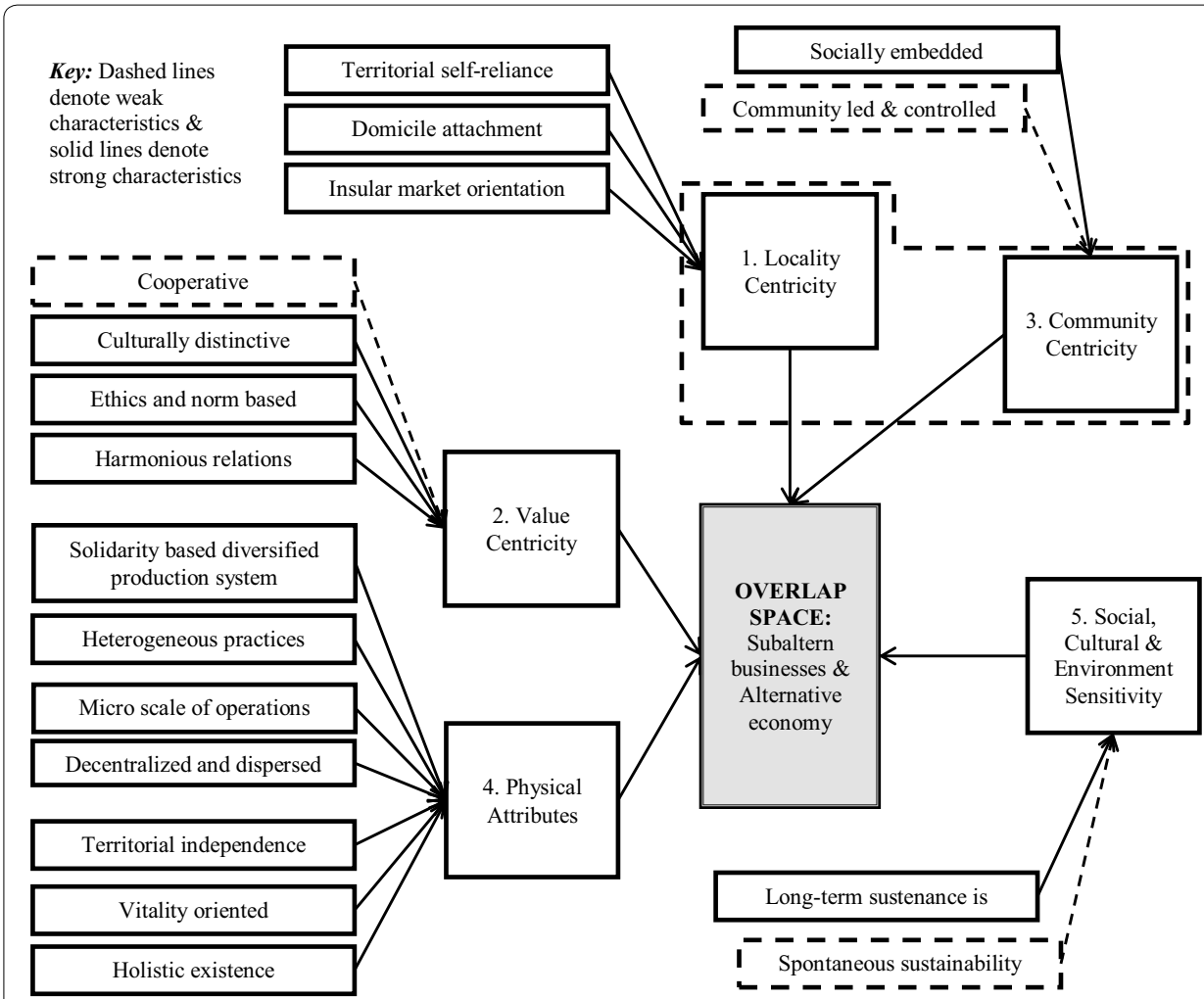

Fig. 3 Overlap space of subaltern businesses and alternative economy. Dashed lines denote weak characteristics and solid lines denote strong characteristics. Source: the figure is a result of the present study

suggested by Stember (1991). Following our qualitative analysis, it is seen that local centricity and community centricity seem to be related. Consequently, these two characteristics are enclosed in a common dashed box.

"Local centricity" as a factor in the subalterns' functioning in their alternative economic network presents a situation wherein the participants are all attached to the village of Mahnar in Vaishali district of the state of Bihar, in eastern part of India. However, all the participants are working in specific areas within the metropolis of Kolkata as street peddlers. The business is territorial self-reliance within the metropolis of Kolkata, and no transactions are made outside the city. Their orientation is towards the local markets. The business is owned by a person who had emigrated from the aforesaid village a long time ago, and ownership is not confined to the local people of Kolkata. Value is not necessarily circulated locally since the profits eventually flow back to the villages from which the subalterns hail.

"Community centricity" seems to be closely related to the characteristic of "local centricity" among the studied subalterns, as indicated in Fig. 3. Analysing the qualitative statements that are relevant to the aspect of "community centricity" (Fig. 3, Table 1), it may be said that while these subaltern peddlers from Bihar are socially embedded and have a reasonable voice in their peddling organization, the ownership is vested with the controller of the peddling organization. The owner of the peddling organization is more akin to the head of a family rather than like the owner of a corporation. The owner takes 
care of his "children" and makes sure that the workers do not suffer owing to occasional drop in revenues. It follows that the alternative economy in which the subalterns work is characterized by social embeddedness, and moderate levels of community lead, and community control. Community ownership and community appropriation are not manifested owing to ownership by a benevolent patriarch.

Subaltern peddlers consider "value centricity" to be a significant factor in their transactions within the alternative economic framework. Business operations are run in a cooperative manner by the culturally cohesive subalterns. However, the business is owned by one subaltern and is not strictly a cooperative enterprise. Transactions are harmonious and based on ethical considerations since all transactions are based on verbal commitments and extralegal accounting methods.

The present study seems to validate all the elements classified under "physical attributes". The subaltern peddlers are reasonably diversified in their manufacturing processes, and the lack of standardization seems to be a defining feature. There are heterogeneous methods of doing business. The overall operations are small scale. The operations are decentred and dispersed with multiple groups of peddlers working in different areas following different modus operandi. Despite being part of a bigger business, each peddler operates independently in his territory his own salesmanship skills (all are males). A vitality-oriented environment (an attractive and conducive economic environment) is crucial to the operation of these subaltern peddlers. The business helps in the upliftment of the whole community of subalterns, extending to the non-working family members back in their village.

On the aspect on "spontaneous sustainability", the subaltern peddlers seemed keen to sustain the business for long enough to let their children also enjoy the fruits of their labour. The villagers take turns to visit Kolkata. Members of a household visit Kolkata for $2-3$ months at a time and, in turn, are replaced by their brethren. This subaltern business is a source of secondary income for the entire village, and the subalterns appear desirous of its long-term survival. Although no specific comments were made on spontaneous sustainability, it is apparent that the manual labour and manual transportation involved in the business operations preclude much of environmental damage or carbon footprint. The aforesaid discussion is represented in Fig. 3. The picture of a typical subaltern peddler, the subject of the present study, is presented in the ensuing subsection.

\subsection{Portrait of a Bhojpuri subaltern peddler}

Bhojpuri is an Indo-Aryan language used in the eastern part of India, as well as the Terai region of Nepal, a bordering country. It is primarily spoken in the western parts of Bihar and the eastern parts of Uttar Pradesh (both are states in India). The MahnarBhojpuri subaltern (since they hail from the village of Mahnar and speak the language named Bhojpuri) is typically a small landholder in his (the person is typically a male) native village in Vaishali district of Bihar, in India. The subjects of the present research are educated only till a primary level and can only read and write a few words in Hindi script, the national script of India. Their average annual family income is only eighty thousand rupees (approximately $\$ 1100$ at prevailing exchange rates in August, 2018). The fragmented nature of his landholding forces him to seek secondary engagements to support his large joint family. While one brother manages the meagre farming assets, 
the subaltern in question leaves his village, catches an overnight train, and goes to the metropolis of Kolkata to work as a peddler in the organization run by Amarnath Shaw. The subaltern peddler sleeps on a mattress spread on the floor of Amarnath Shaw's large warehouse. Nights come early for the subaltern, and sleep comes on at $9 \mathrm{pm}$ every night. The subaltern wakes up at 5:30 am and joins the other members of the organization to fry and cook the eatables using wood-fired or liquefied petroleum gas stoves. After 2-3 $\mathrm{h}$ of cooking and packaging the eatables in sealed transparent polyurethane packets (without any branding), the peddlers step out with their head loads of goods to sell on the streets of Kolkata.

Once the subaltern peddler reaches his assigned traffic crossing or busy thoroughfare in the metropolis, he sells his goods to consumers and collects cash from them. There are no invoices or receipts involved in such transactions. After $7 \mathrm{pm}$, the peddler returns to the warehouse of Amarnath Shaw and hands back all the collected money and the leftover stocks. The stoves are fired up again to cook some rice, lentils, and some vegetable curries for his dinner (non-vegetarian fare is a rare dinner treat). The peddler sits around his friends eating his dinner and gossiping about his family and his experiences for the day. These selling experiences also serve as training cases for the newcomers among the peddlers. After dinner, the subaltern goes to sleep, often playing cards for 15 min before his fatigue gets the better of him.

\section{Conclusion}

The term "alternative market arrangement" has been used to mean an alternative subsystem within a market. The present study sought to extend the existing academic thought on "alternative market arrangement" through a study of the attributes of such an arrangement. A qualitative study of subaltern peddlers, operating within an alternative economic framework on Kolkata, was conducted. Certain attributes were discerned from the narratives recorded during the long interviews with the subaltern peddlers.

The attributes of subaltern peddlers, presented in Fig. 3, may be used for future studies (both qualitative and quantitative ones) on alternative economy. The present study aimed to fathom the characteristics of an organization of subaltern peddlers who operate in an alternative economic framework. The elements identified in Fig. 1 were used as the filter to study their characteristics. Figure 3 depicts the overlap between subaltern business spaces and alternative economic spaces through a study of the characteristics of subalterns operating in alternative economies.

In developing economies, subalterns comprise of a relatively large portion of the total population (Varman and Vikas 2007), and "subaltern economic networks and social environments (SENSEs)" (to introduce a more appropriate terminology) play a pivotal role in the sustenance of subaltern livelihoods. Marketization itself often creates new groups of subaltern from that part of the population which fails to convert capital from their traditional field to the new economic fields (Vikas et al. 2015). Thus, policymakers, scholars, and economic entities may need to be cognizant of the importance of these networks and the reasons thereof.

The contribution in the poverty alleviation of informal economic networks engendered by the subalterns may attenuate concerns about the role of poverty in the occurrence of social flaws such as terrorism (Tugba Kocabiyik 2017) and political uprising by subaltern 
groups (Ortner 1995). "Subaltern peasant revolts" are characterized by strong community solidarity as well as negative opposition to certain perceived exploiters (Chatterjee 2008). In markets where the consumers are predominantly subaltern, governments have a role in creating policy frameworks to resolve the conflicts between poverty alleviation and profit seeking (Varman et al. 2012) and an understanding of subaltern traders may help governments in formulating suitable policies. Such moral dialogues often help in resolving social conflicts (Silver 2018). While the nature of such struggles by subaltern groups is fundamentally bottom up, "the intervention of enlightened outsiders is often a necessary and frustrating complement" (Loftus 2009, p. 326).

The elements presented in Fig. 3 may be used for future studies (both qualitative and quantitative ones) on overlapping phenomenon of subalterns and alternative economy. Statements could be made for each of these elements, and surveys could be conducted of specific alternative economic networks. Development of such an instrument to measure the elements of alternative economic networks falls in the future scope of work.

\section{Authors' contributions}

Both the authors have worked in tandem on the project with the first author conducting the empirical study and the second author analysing the results. Both authors read and approved the final manuscript.

\section{Authors' information}

Dr. Dev Narayan Sarkar has over 14 years' experience in industry and research. He has worked in Coca Cola (Marketing Manager) and Nokia (Regional Sales Manager) before joining PepsiCo. His research interests are in BoP marketing, subalterns and alternative economic networks with more than twenty peer reviewed publications to his credit. He is heading the Eastern Region of India and export markets for PepsiCo, and a part time teacher at eminent business schools. He is a Computer Engineer from Birla Institute of Technology, Mesra, an MBA from FMS, University of Delhi, and a Ph.D. from the University of Calcutta. Dr. Kaushik Kundu has over 16 years' experience in industry, research and teaching and is presently the Head of Department of the Department of Management and Business Administration, Aliah University. He is an MBA from Jadavpur University and a Ph.D. from the University of Calcutta with research interests in organizational culture, marketing to BoP consumers, and alternative economic networks. He is a reviewer for eminent journals. He has more than twenty research publications in peer reviewed journals, seven published book chapters and two complete published books. He is also involved in a number of projects and consultancy works.

\section{Author details}

${ }^{1}$ PepsiCo India, 4A, Akash Tower, 781 Anandapur, Kolkata, West Bengal 700107, India. ${ }^{2}$ Department of Management and Business Administration, Aliah University, 11-A/27, Action Area II, Newtown, Kolkata, West Bengal 700156, India.

\section{Acknowledgements}

The authors do not have anyone to acknowledge.

Competing interests

The authors declare that they have no competing interests.

Availability of data and materials

All the narratives collected during this research are available for scrutiny by the reviewers in the form of Table 1.

Funding

The research described in the present article has not been funded by any person or organization.

\section{Publisher's Note}

Springer Nature remains neutral with regard to jurisdictional claims in published maps and institutional affiliations.

Received: 2 August 2018 Accepted: 8 November 2018

Published online: 19 November 2018

\section{References}

Abdullah I (2016) Remaking from below: the political and policy implications of subaltern experiences in postcolonial Freetown. Afr Zamani 22, 23((2014-2015)):41-59

Amin A (2005) Local community on trial. Econ Soc 34(4):612-633

Arrow KJ (1963) Uncertainty and the welfare economics of medical care. Am Econ Rev 53(5):941-973

Ballamingie P, Walker SM (2013) Field of dreams: just food's proposal to create a community food and sustainable agriculture hub in Ottawa, Ontario. Local Environ 18(5):529-542 
Baskerville R, Dulipovici A (2006) The ethics of knowledge transfers and conversions: property or privacy rights? In: Proceedings of the 39th annual Hawaii international conference on system sciences, 2006. HICSS'06, vol 7. IEEE, p 144b, Jan 2006

Bayat A (2000) From 'dangerous classes' to 'quiet rebels' politics of the urban subaltern in the global south. Int Sociol 15(3):533-557

Beasley-Murray J, Moreiras A (2001) Subalternity and affect. Angelaki J Theor Humanit 6(1):1-4

Belasco WJ (2014) Appetite for change: how the counterculture took on the food industry. Cornell University Press, New York

Benmecheddal A, Gorge H, Özçağlar-Toulouse N (2017) Rethinking alternative markets in the context of economic crisis and austerity in Greece. J Macromark 37(2):193-205

Bergeron S, Healy S (2013) Beyond the business case: a community economics approach to gender, development and social economy. Draft paper prepared for the UNRISD conference: potential and limits of social and solidarity economy, May 2013, pp 6-8. Retrieved 4 Mar 2018 from http://www.communityeconomies.org

Bewley T (2002) Interviews as a valid empirical tool in economics. J Socio Econ 31(4):343-353

Bianchi C, Birtwistle G (2010) Sell, give away, or donate: an exploratory study of fashion clothing disposal behaviour in two countries. Int Rev Retail Distrib Consum Res 20(3):353-368

Binns T, Nel E (1999) Beyond the development impasse: the role of local economic development and community selfreliance in rural South Africa. J Mod Afr Stud 37(3):389-408

Bureau S, Fendt J (2011) Entrepreneurship in the informal economy: why it matters. Int J Entrep Innov 12(2):85-94

Campana M, Chatzidakis A, Laamanen M (2017) Introduction to the special issue: a macromarketing perspective on alternative economies. J Macromark 37(2):125-130

Cassegård C (2012) Play and empowerment: the role of alternative space in social movements. Electron J Contemp Jpn Stud 12(1). Retrieved 17 Apr 2018 from https://japanesestudies.org.uk/ejcjs/vol12/iss1/cassegard.html

Chatterjee P (2008) Democracy and economic transformation in India. Econ Polit Wkly 43(16):53-62

Cochran WG (1977) Sampling techniques, 3rd edn. Wiley, New York

Collom E (2005) Community currency in the United States: the social environments in which it emerges and survives. Environ Plan A 37(9):1565-1587

Combes JL, Hamit-Haggar M, Schwartz S (2018) A multilevel analysis of the determinants of willingness to pay to prevent environmental pollution across countries. Soc Sci J 55(3):284-299. https://doi.org/10.1016/j.soscij.2018.02.001

Curtis F (2003) Eco-localism and sustainability. Ecol Econ 46(1):83-102

Dansero E, Puttilli M (2014) Multiple territorialities of alternative food networks: six cases from Piedmont, Italy. Local Environ 19(6):626-643

Daya S, Authar R (2012) Self, others and objects in an 'alternative economy': personal narratives from the Heiveld Rooibos Cooperative. Geoforum 43(5):885-893

De Haas H (2006) Migration, remittances and regional development in Southern Morocco. Geoforum 37(4):565-580

Denzin NK, Lincoln YS (2002) The qualitative inquiry reader. Sage, London

Dinerstein AC (2003) Power or counter power? The dilemma of the Piquetero movement in Argentina post-crisis. Cap Class 27(3):1-8

DuPuis EM, Gillon S (2009) Alternative modes of governance: organic as civic engagement. Agric Hum Values 26(1-2):43-56

Dyck B (1994) From airy-fairy ideas to concrete realities: the case of shared farming. Leadersh Q 5(3-4):227-246

Escobar A (2001) Culture sits in places: reflections on globalism and subaltern strategies of localization. Polit Geogr 20(2):139-174

Featherstone D (2004) Spatial relations and the materialities of political conflict: the construction of entangled political identities in the London and Newcastle Port Strikes of 1768. Geoforum 35(6):701-711

Fickey A (2011) 'The focus has to be on helping people make a living': exploring diverse economies and alternative economic spaces. Geogr Compass 5(5):237-248

Fraser A, Ettlinger N (2008) Fragile empowerment: the dynamic cultural economy of British drum and bass music. Geoforum 39(5):1647-1656

Frey JH, Fontana A (1991) The group interview in social research. Soc Sci J 28(2):175-187

Galvin M, Thorndahl M (2005) Institutional strengthening of the Amarakaeri Communal Reserve (Madre de Dios River, Peruvian Amazon Basin). Mt Res Dev 25(2):121-125

Gibson-Graham JK (2006) A postcapitalist politics. Minnesota University Press, Minneapolis

Gibson-Graham JK (2016) Building community economies: women and the politics of place. In: Harcourt W (ed) The Palgrave handbook of gender and development. Palgrave Macmillan, London, pp 287-311

Godau R (2004) Qualitative data analysis software: MAXqda and MAXdictio. Qual Res J 4(1):66-78

Godinho V, Venugopal S, Singh S, Russell R (2017) When exchange logics collide: insights from remote Indigenous Australia. J Macromark 37(2):153-166

Gollnhofer JF, Schouten JW (2017) Complementing the dominant social paradigm with sustainability. J Macromark. https ://doi.org/10.1177/0276146717696892

Graham J, Cornwell J (2009) Building community economies in Massachusetts: an emerging model of economic development. In: Amin A (ed) The social economy: international perspectives on economic solidarity. Routledge, London, pp 37-65

Gramsci A (1971) Selections from the prison notebooks (trans. and ed. Hoare Q, Nowell Smith G). International Publishers, New York

Grandia L (2009) Raw hides: hegemony and cattle in Guatemala's northern lowlands. Geoforum 40(5):720-731

Green M (2002) Gramsci cannot speak: presentations and interpretations of Gramsci's concept of the subaltern. Rethink Marx 14(3):1-24

Green M (2011) Rethinking the subaltern and the question of censorship in Gramsci's Prison Notebooks. Postcolon Stud 14:387-404 
Haase M, Becker I, Pick D (2017) Alternative economies as marketing systems? The role of value creation and the criticism of economic growth. J Macromark. https://doi.org/10.1177/0276146717728776

Hankiss E (1988) The "second society": is there an alternative social model emerging in contemporary Hungary? Soc Res 55(1/2):13-42

Hart K, Laville JL, Cattani A (2010) Building the human economy together. The human economy: a citizen's guide. Polity, Cambridge

Hazare A (1997) Ralegan Siddhi: a veritable transformation. Ralegan Siddhi Pariwar Prakashan, New Delhi

Hazlitt H (1979) Economics in one lesson. Crown Business, New York

Heley J, Gardner G, Watkin S (2012) Cultures of local economy in a Celtic fringe region. Eur Urban Reg Stud 19(4):366-382 Homer E (2017) A community economies approach to consignment clothing in Guelph, Ontario. Doctoral dissertation Huybrechts B (2013) Social enterprise, social innovation and alternative economies: insights from fair trade and renewable energy. In: Zademach H-M, Hillebrand S (eds) Alternative economies and spaces. New perspectives for a sustainable economy. Transcript, Bielefeld, pp 113-130

Jacobi S (2016) Pedagogic networks in the visual arts and their engagement with the city of Leipzig. In: Beyond the art school. Gilimore, Ontario, pp 184-200

James J (2015) Mobile phones and safety in developing countries: evidence from Sub-Saharan Africa. Geoforum 62(1):47-50

Kapoor I (2008) The postcolonial politics of development. Routledge, London

Kothari U (2008) Global peddlers and local networks: migrant cosmopolitanisms. Environ Plan D Soc Space 26:500-516

Kröger M (2014) The political economy of global tree plantation expansion: a review. J Peasant Stud 41 (2):235-261

Kumar KS, Babu AS (2013) Prospecting rural supply chain management using a structured approach. Int J Procure Manag 6(3):255-279

Lauria M (1986) The internal transformation of community-controlled implementation organizations. Adm Soc 17(4):387-410

Levi Y (2001) Globalization and the "cooperative difference". J Rural Coop 29(2):105-114

Loftus A (2009) Intervening in the environment of the everyday. Geoforum 40(3):326-334

Loh P, Shear B (2015) Solidarity economy and community development: emerging cases in three Massachusetts cities. Community Dev 46(3):244-260

Marquié JC, Duarte LR (2008) Training older workers and long-term development: needs and obstacles. In: Promotion of work ability towards productive aging: selected papers of the 3rd international symposium on work ability, Hanoi, Vietnam, 22-24 Oct 2007. CRC Press, Hanoi, p 161

Mato D (2000) Not" studying the subaltern," but studying with" subaltern" social groups, or, at least, studying the hegemonic articulations of power. Nepantla Views South 1(3):479-502

Maurer B (2008) Resocializing finance? Or dressing it in mufti? Calculating alternatives for cultural economies. J Cult Econ 1(1):65-78

McCauley SM (2012) Craft economies in Japan: the re-emergence of alternative economies in a no-growth context. In: Lorek S, Backhaus J (eds) SCORAI Europe workshop proceedings: sustainable consumption during times of crisis first trans-Atlantic SCORAI workshop, SCORAl, Bregenz, Austria, 1 May 2012, pp 79-88

McCormack T (1981) Development with equity for women. In: Black N, Cottrell AB (eds) Women and world change: equity issues in development. Sage, Beverly Hills, pp 15-30

McCracken G (1988) The long interview. Sage, Thousand Oaks

McMurtry JJ (2004) Social economy as political practice. Int J Soc Econ 31(9):868-878

Moulaert F, Ailenei O (2005) Social economy, third sector and solidarity relations: a conceptual synthesis from history to present. Urban Stud 42(11):2037-2053

Nadkarni MV (2015) Gandhi's civilizational alternative and dealing with climate change. J Soc Econ Dev 17(1):90-103

Nembhard JG (2006) Principles and strategies for reconstruction: models of African American community-based cooperative economic development. Harv J Afr Am Public Policy 12(1):39-55

North P (2000) Complementary currencies and community economic development in international perspective: problems and how they might be overcome. In: International Network of Engineers and Scientists for Global Responsibility conference, Stockholm, Sweden, June 2000

North P (2010) The longevity of alternative economic practices: lessons from alternative currency networks. Interrogating alterity: alternative economic and political spaces. Routledge, London, pp 31-46

North P (2016) The longevity of alternative economic practices: lessons from alternative currency networks. Interrogating alterity. Routledge, New York, pp 71-86

North P, Huber U (2004) Alternative spaces of the "Argentinazo". Antipode 36(5):963-984

Odusola AO, Hendriks M, Schultsz C, Stronks K, Lange J, Osibogun A, Akande T, Alli S, Adenusi P, Agbede K, Haafkens J (2011) Development and evaluation of a patient centered cardiovascular health education program for insured patients in rural Nigeria (QUICK-II). BMC Public Health 11(1):171-183

Ofstehage A (2012) The construction of an alternative quinoa economy: balancing solidarity, household needs, and profit in San Agustín, Bolivia. Agric Hum Values 29(4):441-454

Ortner SB (1995) Resistance and the problem of ethnographic refusal. Comp Stud Soc Hist 37(1):173-193

Painkra M, Dutta J, Ranga MM (2017) Status survey of non wood forest products in Surguja district of Chhattisgarh: India. J Appl For Ecol 5(2):20-27

Parkins W, Craig G (2009) Culture and the politics of alternative food networks. Food Cult Soc 12(1):77-103

Perkins HA (2011) Gramsci in green: neoliberal hegemony through urban forestry and the potential for a political ecology of praxis. Geoforum 42(5):558-566

Rethel L (2011) Whose legitimacy? Islamic finance and the global financial order. Rev Int Polit Econ 18(1):75-98

Reysen S, Hackett J (2017) Activism as a pathway to global citizenship. Soc Sci J 54(2):132-138

Salvatore RD (2003) Wandering Paysanos: state order and subaltern experience in Buenos Aires during the Rosas era. Duke University Press, Durham 
Sarkar DN (2013) Conceptual framework for designing a rural distribution model for mobile telecom operators in India. Splint Int J Prof 1(1):28-39

Sassen S (1990) The mobility of labor and capital: a study in international investment and labor flow. Cambridge University Press, London

Sharp J (2011) A subaltern critical geopolitics of the war on terror: postcolonial security in Tanzania. Geoforum 42(3):297-305

Sharpe J, Spivak GC (2003) A conversation with Gayatri Chakravorty Spivak: politics and the imagination. Signs J Women Cult Soc 28(2):609-624

Shear BW (2014) Making the green economy: politics, desire, and economic possibility. J Polit Ecol 21(1):193-209

Shuman M (2013) Going local: creating self-reliant communities in a global age. Routledge, London

Silver H (2018) Sociology: moral dialogues and normative change. Soc Sci J 55(1):19-22

Smith A (2012) The insurmountable diversity of economies. Blackwell, Chichester

Spivak GC (1990) Gayatri Spivak on the politics of the subaltern. Interview with H. Winant. Soc Rev 20(3):85-97

Spivak GC (1992) Interview with Gayatri Chakravorty Spivak: new nation writers conference in South Africa by Leon de Kock. ARIEL Rev Engl Lit 23(3):29-47

Spivak GC (2000) The new subaltern: a silent interview. In: Chaturvedi V (ed) Mapping subaltern studies and the postcolonial. Verso, London, pp 321-334

Spivak G (2003) Subaltern studies. Deconstr Crit Concepts Lit Cult Stud 4(1):220-232

Srivastava M, Goel D, Semwal J, Gupta R, Dhyani M (2015) Posttraumatic stress disorder symptoms in the population of Uttarkashi, Tehri, and Pauri Garhwal India in reference to Uttarakhand flood—June 2013. Int J Health Syst Disaster Manag 3(5):37-43

St. Martin K (2007) The difference that class makes: neoliberalization and noncapitalism in the fishing industry of New England. Antipode 39(3):527-549

Steele W (2012) Do we need a 'slow housing' movement? Hous Theory Soc 29(2):172-189

Stember M (1991) Advancing the social sciences through the interdisciplinary enterprise. Soc Sci J 28(1):1-14

Stoecker R (1997) The CDC model of urban redevelopment: a critique and an alternative. J Urban Aff 19(1):1-22

Storr VH, Butkevich B (2007) Subalternity and entrepreneurship: tales of marginalized but enterprising characters, oppressive settings and haunting plots. Int J Entrep Innov 8(4):251-260

Thompson CJ (2014) The politics of consumer identity work. J Consum Res 40(5):iii-vii

Tolley B, Hall-Arber M (2015) Tipping the scale away from privatization and toward community-based fisheries: policy and market alternatives in New England. Mar Policy 61(1):401-409

Touri M (2016) Development communication in alternative food networks: empowering Indian farmers through global market relations. J Int Commun 22(2):209-228

Tugba Kocabiyik E (2017) Subalterns approach to chain supermarketization: modern grocery retailers versus independent small grocers. In: Belk RW (ed) Qualitative consumer research. Emerald Publishing, Bingley, pp 95-110

Vanolo A (2013) Alternative capitalism and creative economy: the case of Christiania. Int J Urban Reg Res 37(5):1785-1798

Varman R, Belk RW (2008) Weaving a web: subaltern consumers, rising consumer culture, and television. Mark Theory 8(3):227-252

Varman R, Vikas RM (2007) Freedom and consumption: toward conceptualizing systemic constraints for subaltern consumers in a capitalist society. Consum Mark Cult 10(2):117-131

Varman R, Skålén P, Belk RW (2012) Conflicts at the bottom of the pyramid: profitability, poverty alleviation, and neoliberal governmentality. J Public Policy Mark 31(1):19-35

Velayudhan SK (2014) Outshopping in rural periodic markets: a retailing opportunity. Int J Retail Distrib Manag 42(2):151-167

Vikas RM, Varman R, Belk RW (2015) Status, caste, and market in a changing Indian village. J Consum Res 42(3):472-498 Westlund H (2003) Form or contents? On the concept of social economy. Int J Soc Econ 30(11):1192-1206

Wright S (2010) Cultivating beyond-capitalist economies. Econ Geogr 86(3):297-318

Xie PF (2010) Authenticating ethnic tourism. Channel View Publications, Bristol

\section{Submit your manuscript to a SpringerOpen ${ }^{\circ}$ journal and benefit from:}

- Convenient online submission

- Rigorous peer review

- Open access: articles freely available online

- High visibility within the field

- Retaining the copyright to your article

Submit your next manuscript at $\boldsymbol{\nabla}$ springeropen.com 